\title{
Repair of the rectovaginal fistula in the mare - a new surgical approach
}

\author{
E. Klug', A.J.S. Almeida-Sampaio and Heike Aupperle² \\ 'Klinik für Pferde der Tierärztlichen Hochschule Hannover, ${ }^{2}$ Institut für Veterinärpathologie der Universität Leipzig
}

\begin{abstract}
Summary
It was the aim of the study to develop a new surgical method to repair the so called rectovestibulum fistula (RVF) in the horse: In this context it was intended to combine and take up advantageous aspects of methods already established in plastic surgery for this traumatically caused defect. Known disadvantages of the different methods such as surgical transfer of the fistula to a third degree perineal laceration, difficult practicability and high incidence of recidives were minimized. The primary aspect of the new surgical method is the surgical transfer and inclusion of a second degree perineal laceration by which main parts of the perineal body and shincter ani in toto are maintained.

After training phases for general feasability of the new procedure surgery was simulated on isolated pelvic organs $(n=15)$ and in straight before sacrified animals $(n=8)$ the operations were performed on 6 experimental and 4 client mares.

The healing process until the removal of the sutures was without any clinical complications. On the average the clinical healing of the fistula operated was completed after two weeks. Complications such as intestinal constipation, tenesmus, excessive inflammatory reactions or general worsening of well-being of the mares did not show up in any case. In 8 of 10 cases the fistula was completely closed after a first surgery. In two (experimental mares) of the 10 cases there was a recidive of a now considerable smaller fistula which was in one mare closed and healed after a second surgery. In one of these two mares a second recidive occured demanding a third surgery session. Ultrasound measurements revealed a remarkable increase of the interrectovestibular tissue. After euthanasia of the experimental mares pathologicalanatomical and histological examinations of the rectal bottom and vestibulum roof within the area of the surgical site revealed similar results in all samples prooving a definite healing with scars which has to be regarded as stable. As a conclusion it can be stated that the new established plastic surgery of RVF can be recommended for practical use as it fulfilled the main aims of (1) durable and stable surgical closure of the RVF, (2) maintenance of integrity of the closing function of the anal sphincter, and (3) reliable external genital closure.
\end{abstract}

Keywords: $\quad$ mare, rectovaginal fistula, plastic surgery, perineal integrity

\begin{abstract}
Verschluss der Rekto-Vaginalfistel bei der Stute - eine neue chirurgische Methode
Die vorliegende Studie hatte als Aufgabe eine neue Methode der plastischen Rectovestibulumfistel-Operation (RVF) zu entwickeln. Hierbei sollten die Vorteile bisher beschriebener Operationsverfahren für diesen traumatisch bedingten Defekt übernommen und kombiniert und vor allem sollten deren Nachteile, wie Überführung der RVF in einen Dammriss dritten Grades, geringe Praktikabilität und hohe Rezidivrate vermieden oder zumindest minimiert werden. Der vorrangige Aspekt der neuen Operationsmethode ist die Überführung und Übernahme der RVF in einen artifiziellen Dammriss zweiten Grades. Hierbei bleiben der Perinealkörper zum größten Teil und der Afterschließmuskel in toto erhalten.

Nach einer Einübungsphase mit Operationstraining an 15 isolierten Beckenorganen und an 8 frischtoten Stuten wurde die neve Operationsmodifikation an 6 Experimentier- und an 4 Klientenstuten durchgeführt. Der Heilungsprozess bis zur Entfernung der Nähte - im Mittel ca. 14 Tage - verlief ohne klinisch erkennbare Komplikationen. Denkbare Komplikationen bei den diätetisch vorbereiteten Stuten (Öl, Weizenkleie) wie Obstipationen, Tenesmen, überschießende entzündliche Reaktion u.Ä. oder Störungen des Allgemeinbefindens wurden in keinem Fall beobachtet. In 8 von 10 Stuten erwies sich die Fistel nach erster Operation als vollständig verschlossen. Bei zwei Stuten (Experimentierstuten) stellte sich ein Rezidiv der Fistel mit nun aber erheblich redizierten Dimensionen ein, sodass eine zweite Operation erforderlich wurde, die bei einer dieser Stuten erfolgreich war und bei der anderen von einem zweiten Rezidiv gefolgt war und eine dritte Sitzung erforderte. Ultrasonographische Messungen ergaben eine deutliche Zunahme der rektovestibulären Zwischengewebeschicht. Pathomorphologische Untersuchungen des Rektumbodens und des Vestibulumdaches im Bereich der Operationslokalisationen der euthanasierten Experimentierstuten belegen eine vollständige, vernarbte und als stabil einzuschätzende Abheilung. Es kann nach allen Untersuchungsergebnissen abgeleitet werden, dass die neue operative Plastik der RVF für die Praxis empfohlen werden kann und die drei wichtigen Anforderungen an eine solche (1) daverhafter und stabiler Verschluss der Fistel, (2) Erhaltung der perinealen Integrität und (3) verlässlicher Schamschluss erfüllt.
\end{abstract}

Schlüsselwörter: Stute, Mastdarm-Scheidenfistel, plastische Operation, perineale Integrität

\section{Introduction}

The rectovaginal fistula (RVF) in mares is a chronic complete disconnection of the tissue in the area of the hinder preanular part of rectum bottom and prevulvar region of the vestibular roof without inference of the perineal body (Götze, 1952; Ansari \& Matros, 1983; LeBlanc, 1998). It arises primarely from severe trauma by the passing fetus during second stage of labour (Colbern et al., 1985; Dreyfuss et al., 1990; Huber 1998). Secundarely a RVF can be established as a partial reci- dive of the surgical closure of a perineal laceration of third degree (Klug, 1999). If not repaired immediately after birth trauma - its success is controversely discussed among clinicians (Nickels, 1979; Larsen, 1983; Wollrab, 1984) - wound healing per secundam intentionem will occur and form a more or less circular fistula bringing the mucous membranes of the rectum and the vestibulum tightly together. While general health and comfort of the mare is hardly affected by RVF continuous con- 
tamination of the genital tract with enteral contents causing infertility is the inevitable consequence demanding plastic surgery to restore interrecto-vestibular tissue barrier and continue perineal confor-mation (Greenaway, 1960; Dietz \& Henschel, 1988) Belknap und Nickels, 1992)

Two main principles of plastic surgery of RVF in the mare are described. The one is sagital transsection of the perineal corpus completing artificially RVF to a perineal laceration of third degree, horizontal dissection of the circular margin between rectal and vestibular membrane of the RVF and mobilisation of the tissue of the adjacent membrane tissue from the basis. Wound closure is performed by singular sutures with monofil suture material which grasp towards the lateral and dorsal submucuous tissue of the vestibulum und backwards the margins of the dissected vestibular mucus membran (Aanes, 1974; Merkt und Merkt, 1986; Mair et al., 1998). The rectal mucosa may be sutured (Walker and Vaughan, 1980) or remains unsutured (Papa et al., 19929). The anal sphincter remains unsutured allowing defaecation without stressing peristalsis. This operation, performed in more than one sessions, has the advantage of a good heeling tendency and low risk of recidives. The disadvantage is some incontinence of fecal liquid phases and in some cases air sucking into the rectum may be causing irritation of the mare.

The other principle is saving both the rectal sphincter and the dorsal vulval commissure with an transperineal approach to the RVF by a horizontal transsection of the perineal corpus between rectal bottom and vestibular roof towards the RVF (Walker and Vaughan, 1980; Colbern et al. 1985; Slusher, 1987 Beard, 1991). This transection is continued horizontally through the fistula about 3-4 cm cranially beyond the lesion. The defect of the rectum is closed with submucosal longitudinal sutures ensuring a transversal adaptation of the cranial and caudal margin of the lesion to minimize peristaltic stress on the suture line. The vestibular opening of the fistula is repaired by transversal submucosal sutures forming a longitudinal orientation of the suture line which is now in a right angle position to the suture line of the rectum. The dead space remaining between rectum and vestibulum is closed by interrupted sutures with absorbable material (Walker and Vaughan, 1980) or even left unsutured (Desjardins et al., 1993). The perineal skin incision is closed with simple sutures with nonabsorbable suture material. The advantage of this method is the maintaining of the integrity of the perineal body and the anal sphincter. The disadvantage is the higher risk of recidives due to manure leakage into the wound causing healing irritation and suture dehiscens (Klug, 1999).

The new repair surgery presented here tries to combine the advantages of both the principles cited above and avoid their disadvantages. The new approach comprises the repair of the RVF into the surgical closure of an artificially acut incised perineal laceration of second degree.

\section{Materials and methods}

\section{Animals and dummies}

The surgery was performed in 6 experimental (4 standardbred, 2 warmblood) mares 4 to 18 years of age, body weight 450 -
$550 \mathrm{~kg}$, and in 4 clients ( 3 warmblood, 1 arab) mares ageing 6- 12 years.

For a step by step establishement of the new surgical plastic operations of the experimental mares were preceeded by dummy surgery on isolated exteriorizid pelvic organs including complete rectum and genital tract $(n=15)$ followed by dummy operations in 6 freshly euthanized mares whose hindpart had been brought into an almost normal upright body position $(n=8)$. In all these experiments a ,fresh' RVF was installed immediately followed by the new repair method in order to practice the different parts of the new surgical plastic and become skilled in the suture technic.

The distance from rectum bottom to the vestibular roof in the predisposed site of the artificial fistula was ultrasonographically measured before the installation and after the postoperative healing period using a $5 \mathrm{MH}$ ultrasound transducer. Measurements were performed at two sites. Location A was 2 $\mathrm{cm}$ cranial the anal sphincter and location B $2 \mathrm{~cm}$ caudal the hymenal ring.

\section{Mares' preparation for surgery}

All operations were performed in the mares standing in upright position restrained in a stock. For sedation they got $0.08 \mathrm{mg} /$ $\mathrm{kg} / \mathrm{BW}$ IV romifidine hydrochlorid (Sedivet 1\%, Boehringer Ingelheim Vetmedica $\mathrm{GmbH}, 55216$ Ingelheim). Epidural anaesthesia was performed by injection of $1.20 \mathrm{ml} / 100 \mathrm{~kg} / \mathrm{BW}$ lidocaine hydrochloride (Xylocain 2\%, Astra Chemicals GmbH, 22880 Wedel) into intervertrebral space between last sacral and first coccygeal vertebrae.

For additional anaesthesia of whole caudal pelvic region the perineal body, the retroperitoneal part of vagina and rectum, and the perineal skin were infiltrated with $80 \mathrm{ml}$ Lidocain-hydrochlorid (Xylocain 2\% with adrenaline 1 : 200.000, Astra Chemicals $\mathrm{GmBH}, 22880$ Wedel) using a $24 \mathrm{~cm}$ infiltration canula (Medicalis Medizintechnologie $\mathrm{GmbH}, 30827$ Garbsen). The whole intern and extern operation site was cleansed with warm water and washed with mild desinfectant $(0.03 \%$ polyvidon-jodpropanol solution - Braunol 2000, Lehnecke GmbH, 26419 Schortens) and the tail totally wrapped in a bandage.

\section{Installation of the artificial RVF}

The artificial RVF was installed by a 3 to $4 \mathrm{~cm}$ longitudinal incision beginning ca. $5 \mathrm{~cm}$ cranial of the anus through rectum bottom and vestibular roof followed by widening and stretching the incision by putting all fingers of one hand into the opening which was afterwards, drained' with a loop of gauze bandage material for some days in order to prevent adhesion of the wound lips. Healing per second intention occurred within 14 days followed by a marked shrinking of the RVF within the third post surgical week.

The new surgical procedure of RVF repair

Preparation and anesthesia of the probands was done in strict accordance with those described above. Visualization of the inner vestibulum and the vestibular aspect of the RVF was performed by one retraction suture fixed in the labial skin on 
each side and one through the perineal skin about $1 \mathrm{~cm}$ dorsal the upper vulvar commissure (fig. 1).

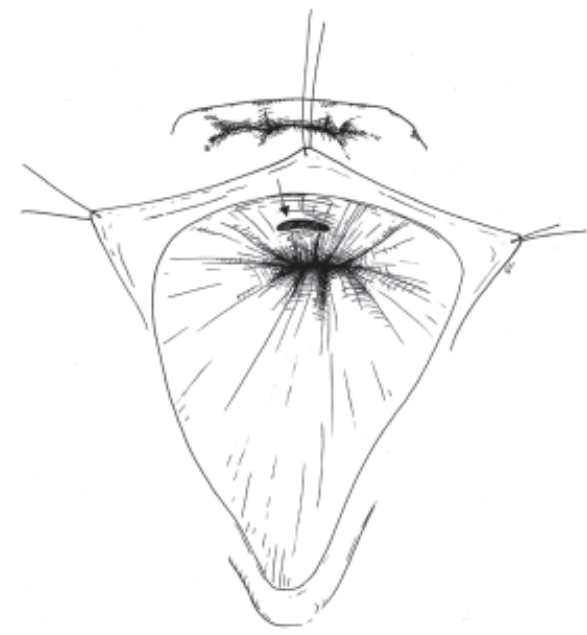

Fig. 1: View on the operation site with 2 lateral (labial) und 1 dorsal (perineal) retraction sutures

Ansicht des Operationsfeldes mit je einem lateralen (labialen) und einem dorsalen Zügel

The proper surgery consists of five steps:

$1^{\text {st: }}$ dorsal incision through the vestibular mucous membrane about two $\mathrm{cm}$ deep into the perineal body from the hind part of the RVF (fig. 2a) to the upper vulvar commissure mimiking a second degree perineal laceration (fig. $2 b$ ).

$2^{\text {nd }}$ : separation of both the mucous membranes of the rectal and vestibular part of the RVF by circumcision and incision into the surrounding tissue lateral and beyond (cranial) the RVF (fig. 2c). $3^{\text {rd }}$ : preparation of the wound as for perineoplasty (Merkt und Merkt. 1986) i. e. separation of the mucous membrane from the underlying tissue dorsolateral on the left and right side of the vestibulum wall from the caudal brim of the RVF to lips (fig. 3 ) the dorsal part of the vulva. By this procedure the RVF now forms the cranial part of the perineal laceration.

$4^{\text {th }}$ : closure of the wound starts with a first transversal, oblique' suture (Supramid 8, metric, white, B. Braun-Dexon GmbH, 34268 Spangenberg) beginning $2 \mathrm{~cm}$ beyond the cranial edge of the vestibular part of the RVF crossing to the ipsilateral side 2 $\mathrm{cm}$ behind and under the caudal edge of rectal part of the RVF (fig $2 \mathrm{~d}$ and 4).

$5^{\text {th }}$ : completion of the repair as for routine perineoplasty (fig. 5). The opening of the rectum mucous membrane remains unsutured for their woundlips quickly adhere together.

Twelf hours before operation started the mares got 2 I paraffine oil (Paraffininum perliquidum, Fa. WDT e.G, 30812 Garbsen) per oesophagus tube. Post surgery each mare got penicilline and streptomycinesulphate $(35 \mathrm{ml}$ Omnamycin Hoechst Roussel Vet Vertriebs $\mathrm{GmbH}, 85716$ Unterschleissheim) daily for 5 days and additionally $1 \mathrm{mg} / \mathrm{kgBW}$ Flunixin-Meglumin (Finadyne, Exssex Tierarznei 81737 München) per day.

The perineal wound site was daily cleaned and protected with ointments. Food consisted of hay ad libitum and $1 \mathrm{~kg}$ wheat bran per day. Stitches were cut and removed about two weeks after operation and site of repair was checked by palpation and its structure controlled by rectally applied ultrasound.
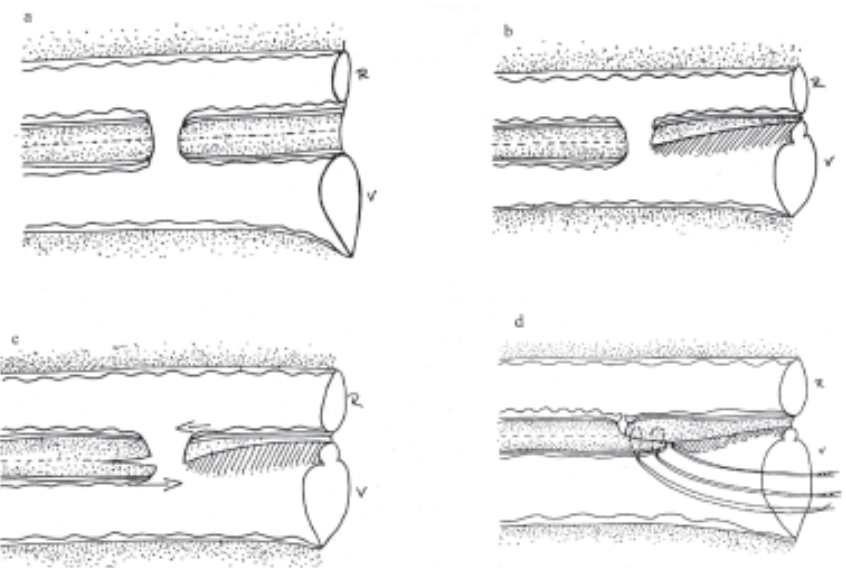

Fig. 2: Schematic drawing of the main steps of the surgery: (a) pre surgical, (b) cutting the artifical perineal laceration $2^{\text {nd }}$ degree, (c) circumsision for separation rectal and vestibular mucosa, (d) caudal shifting vestibular part of RVF beneath caudal intact rectal bottom and sutures

Schema der wichtigsten Schritte der Operation: (a) preoperative Situation, (b) Anlage des artifiziellen Dammrisses 2. Grades, (c) Zirkumzision in der RVF zur Trennung der rektalen und vestibulären Mukosa, (d) Zug des vestibulären Anteils der RVF unter den intakten Rektumboden und Nähte

Four weeks after surgery the experiental mares were sacrified and the isolated repair sites underwent post mortem examination followed by pathohistologically analysis.

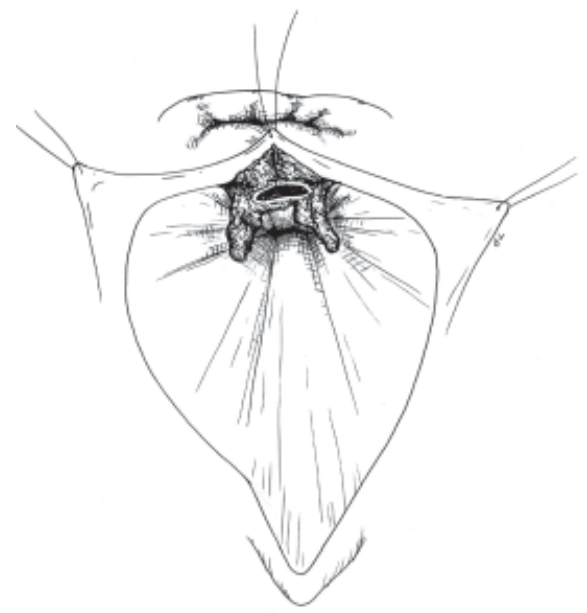

Fig. 3: View on the operation site: perineal laceration $2^{\text {nd }}$ degree is installed and dorsal vestibular mucosa is separated from underlying tissue

Ansicht des Operationsfeldes nach Anlage des Dammrisses 2. Grades und Präparation der dorsalen Vestibulummukosa

\section{Results}

The dummy surgery in isolated pelvic anorectal and perineal organs as well as operation on the still warm carcase of the euthanized experimental mares provided good possibilities for training and improving the surgery technique. Immobilization of the experimental as well as client mares were sufficient and the performed local anaesthesia provided a painless operation area. The proper time of surgery was about one hour per session and the personnel consisted of 1 surgeon, 1 assistant, 1 person for holding the retraction sutures and another one in front of the stock to keep the mare. 


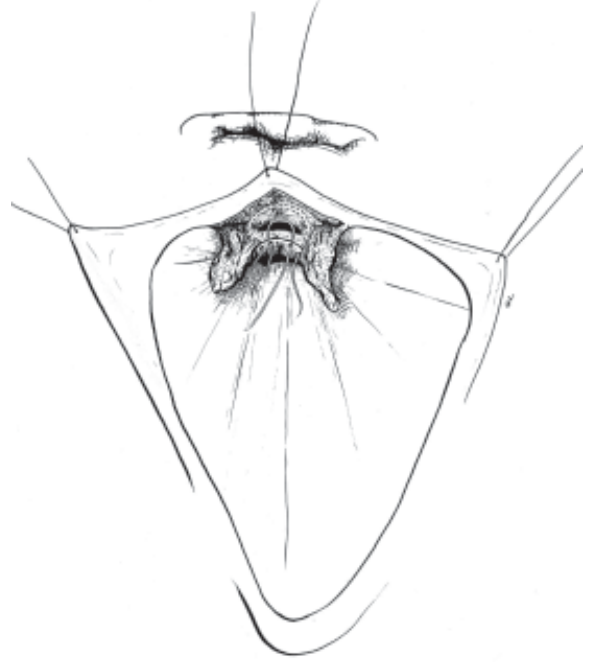

Fig. 4: Direction of the suture which goes from the cranial edge of the vestibular part of the RVF under the caudal edge of the rectal part of the RVF

Fadenführung mit doppelter Durchstechung und seitlicher Knüpfung; Faden erfasst den kranialen Rand des vestibulären Anteils der RVF und führt ihn unter den kaudalen Rand des rektalen Anteils der RVF

Tab. 1 contains data from the measures of the tissue thickness between caudal rectum and vestibulum. A remarkable increase of the distance between rectum bottom and vestibular roof after healing period could be measured.

The results of the new surgery of RVF and its postsurgical events are summarized in table 2 . While space of time between installation of the RVF and surgery was unique 14 days in the experimental mares it was up to 18 months in the client mares. In one mare time of the trauma could not be ascertained. Mean largest diameter of the fistulas was $4.9 \mathrm{~cm}$ with a wide range from 2 to $11 \mathrm{~cm}$ and their shape varied from circle to longitudinal or transverse oval form.

Only mild to modest bleeding occured during surgery which ceased spontaneously or could be brought under control very quickly by slight compression or finally by the sutures. With one exception liberation of mucous tissue was easy to fair in all the experimental mares. Tissue mobilization in the clients was fair to difficult due to

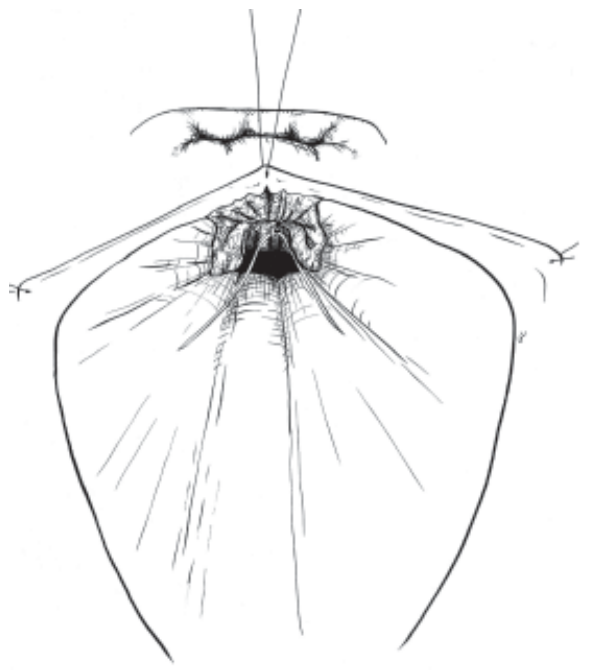

Fig. 5: Subsequent repair of the artifical $2^{\text {nd }}$ degree perineal laceration by Goetze-Technic

Verschluss artifiziellen Dammrisses nach der Götze-Technik the fibrotic scars. In most cases survey of the surgical site was good to fair and in 2 cases survey was limited because of the very voluminous semitendineus muscles narrowing the cleft between the thighs. Healing proceeded continuosly during following post surgery days and was completed on day 14 after operation when
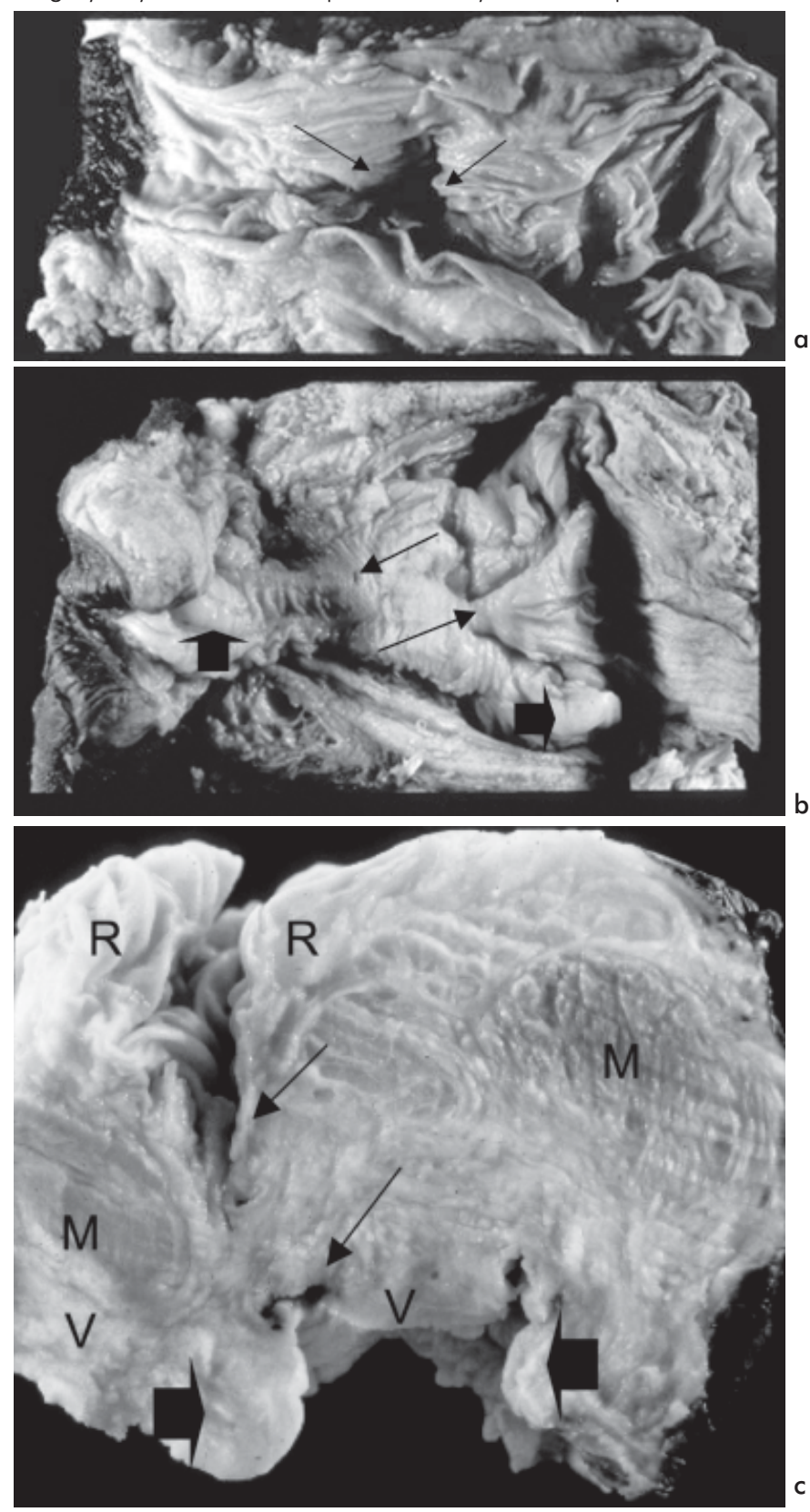

Fig. 6: Operation site post mortem (formol fixation):

(a) navellike scare (arrows) in the rectal mucosa,

(b) vestibulum mucosa with normal folds (short arrows) and navellike scares (long arrows),

(c) cross section of a healed RVF; navellike scares (long arrows) of rectal mucosa (R), folds (short arrows) of vestibular mucosa (V), and musculature $(M)$

Post mortem Operationsgebiet (Formolfixation):

(a) narbige Einziehung in der Rektum-Schleimhaut (Pfeile),

(b) Vestibulumschleimhaut mit normalen Falten (kurze Pfeile) und narbige Einziehungen (lange Pfeile),

(c) Schnitfläche durch eine abgeheilte RVF; narbige Einziehungen (lange Pfeile) der Rektumschleimhaut (R), Schleimhautfalten der Vestibulumschleimhaut (V) und Muskulatur (M) 
sutures were removed. In 2 experimental mares recidives of the RVF occured. In one of them the recidive fistula sized half of the origin one and could be repaired in a second surgery 14 days later. In the other mare second operation failed again demanding a third operation 3 weeks later which was initially successfull but failed again later. Defaecation was normal in all probands. Perineal conformation in most cases was improved after surgery comparing to the status before.

Post surgery breeding records are available from 3 of the 4 client mares. Two of them got in foal the following season and one in the second following seaon. The fate of the fourth mare remains unknown.

Gross pathomorphological examination of the excorporated tissue of the operation site revealed a circumscript navel shaped profound $3 \times 6 \mathrm{~cm}$ scared areal in the rectal mucous (fig. 6a) membrane as well as in the vestibular mucosa with a $6 \times 1 \mathrm{~cm}$ scared region (fig. 6b). Cross section of the surgery site demonstrated the thick connective tissue layer between rectal and vestibular scars (fig. 6c). Thickness of rectal mucosa in the scared area measured $0.2 \mathrm{~cm}$ compared to $0.5 \mathrm{~cm}$ in the surroundings whereas vestibular mucous membrane in the surgery site was $0.3 \mathrm{~cm}$ thick very similar to the surroundig mucosa.

Pathohistological findings of the surgery location site were similar in all cases. The villi of rectum mucosa, the mucosa itself and submucosa cranial and caudal of the wound were normal containing only few lymphocytes, plasma cells and very few eosinophils. The tunica muscularis was normal. The scars itself consisted of metaplastic squamous epithelium up to 10 layers (fig. 7a).

The scars surroundig area in the vestibulum was protected by cornified squamous epithelium in 5 to 10 layers. Within the epithelium and subepithelium a slight infiltration of lymphocytes and neutrophils was observed. The muscle layers were normal. Folds of vestibular mucosa within the surgery site consisted of loose collagen enriched connective tissue with only few blood vessels and protected by squamous epithelium with fewer number of layers compaired to neighboured epithelium (fig. 7b).

In the proper site of the scars submocosa and muscularis of the rectum and vestibulum were replaced by a mature collagen

Fig. 7: Pathohistological slides (H.E. staining, magnification 62.5 ) of operation site:

(a) rectal mucosa with a marked transition (arrow) from normal rectal mucosa (D) to cornifying squamous epithelium (P) underlayed by musculature (M),

(b) vestibular mucosa in the healed operation site with remarkable reduced thickness of the squamous epithelium (E) compared to the normal tissue $(P)$ and multifocal stromal infiltration of inflammatoric cells (arrows),

(c) granulation tissue: collagen enriched, less vascularized connective tissue in the musculatur indicating a complete organization of the scar tissue; single irregular muscle fibers $(M)$ surrounded by straight forward collagen fibers $(K)$

Pathohistologischer Schnitt (H.E. Färbung, Gerätevergrößerung 62,5x):

(a) scharf abgegrenzter Übergang (Pfeil) von der normalen Darmschleimhaut (D) zu dem verhornenden Plattenepithel (P) unterlegt von Muskulatur (M),

(b) Vestibulumschleimhaut; im Bereich der OP-Wunde deutliche verminderte Dicke des Plattenepithels (E) im Vergleich zum unveränderten Gewebe (P); multifokale Enzündungszell-Infiltrationen (Pfeile),

(c) Granulationsgewebe: kollagenreiches, gefäßarmes Bindegewebe in der Muskulatur als Ausdruck einer vollständigen narbigen Organisation; vereinzelt irregulär Verlaufende Muskelfasern (M) umgeben von gerichtet verlaufenden Kollagenfasern (K)
Tab.1: Distance $(\mathrm{cm})$ between caudal rectum bottom and vestibular roof measured $2 \mathrm{~cm}$ cranial the anal sphincter (location A) and $2 \mathrm{~cm}$ caudal the hymenal ring (location B) before and after surgery ultrasonographical measurement)

Schichtdicke (cm) zwischen kaudalem Rektumboden und Vestibulumdach $2 \mathrm{~cm}$ kranial des Analsphinkters (Lokalisation A) und $2 \mathrm{~cm}$ kaudal des Hymenalrings (Lokalisation B) und nach der chirurgischen Plastik (Ultra-Sonographiemessungen)

\begin{tabular}{|l|c|c|}
\hline & location A & location B \\
\hline before surgery & 2,9 & 1.9 \\
& $1.3-3.8$ & $0.7-2.4$ \\
\hline \multirow{2}{*}{ after surgery } & 3.8 & 2.6 \\
& $2.4-4.6$ & $1.4-3.8$ \\
\hline
\end{tabular}

enriched connective tissue infiltrated by single irregular muscle fibers and by single elastic fibers with focal hemosiderine containing macrophages (fig. 7c).
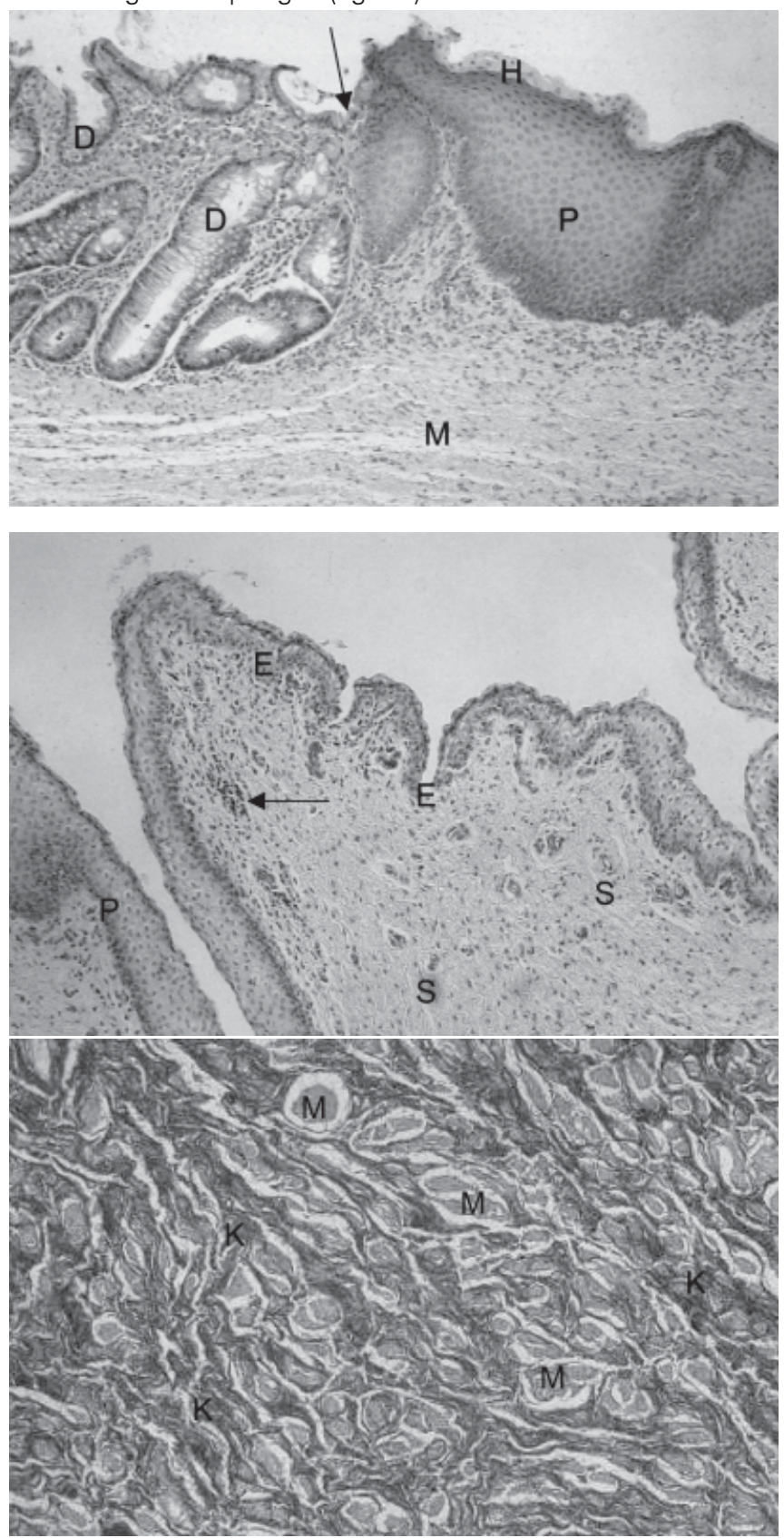


\section{Discussion}

All the fistulas as the artificial ones in the experimental mares as well as the accidental ones in the client mares were located in the typical rectovestibular site described by many authors. Also their shape and dimensions were within the range cited from literature (Rudolph, 1976; Rossdale und Ricketts, 1983; Grunert 1993). Therefore it can be concluded that the group of mares treated in this study represented a normal client population of mares bearing a RVF. Inspite the fact that the artificial RVF in the experimental mares had been installed in exactly the same manner the dimensions and the form of the final RVF varied widely but were not surprising. The healing process naturally in second intention could not be visualized from outside and not be influenced. By these reasons dimensions and form of RVF ocurred accidentally. Restriction of the mare in a stock and tranquilization with an alphareceptor agonist adopted from own clinic practise and other reports (Walker und Vaughan, 1980; Wollrab, 1984; Beard, 1991) achieved a sufficient immobilization of all the operated mares. Epidural anaesthesia in a dosage used in this study is able to maintain the horse in a standing position and will anaesthesise the inner part of the vestibulum but it will not include the perineal, vulval, and perivulval skin. For that reason additional anaesthesia by deep infiltration into the perineal body and into the perivestibular tissue was necessary (Merkt und Merkt, 1986; Nudelmann, 1989). The operation procedure in this study needed a four persons staff which under practical conditions may be reduced down to two by releasing the operation assistent and the mare keeper. The 60 minutes duration of the surgery seems similar to conventional procedures. The used suture material proved to be very practicable. It provided enough tensile strength and was well tolerated by the surrounding tissue. Controversely to other opinions (Ansari und Matros, 1983; Shokry et al., 1986; Fontiine, 1992) recommending reabsorble suture material the results from this study revealed no disadvantages of monofile nonreabsorble material. The postoperation phase in all the probands was completely undisturbed. Defaecation reflexes of the rectum und the anal sphincter functioned normal. Advantageous was clearly the dietary measurements as oral application of oil and additional feeding of wheat bran as recommendet by several surgeons (Schulz et al., 1984; Vaughan, 1984; Slone, 1993).

The incision forming an artificial perineal laceration of $2^{\text {nd }}$ degree achieved a good survey on to the operation field exposing the fistula itself to good visualization enabling circumcision and

Tab. 2: Results of surgical RVF - repair and post surgical development in 6 experimental and 4 client mares

Ergebnisse des chirurgischen RVF-Verschlusses und post operative Entwicklung bei 6 Experimentier- und 4 Klientenstuten

\begin{tabular}{|c|c|c|c|c|c|c|c|c|c|c|c|c|c|}
\hline & \multirow{3}{*}{$\begin{array}{l}\text { mare } n^{\circ} \\
\text { lage }\end{array}$} & \multirow{3}{*}{$\begin{array}{l}\text { days of } \\
\text { fistula } \\
\text { estab- } \\
\text { lishment } \\
\text { / op }\end{array}$} & \multirow{3}{*}{$\underset{(\mathrm{cm})}{\varnothing_{i s t u l a}}$} & \multirow{3}{*}{$\begin{array}{l}\text { form of } \\
\text { fistula }\end{array}$} & \multicolumn{3}{|c|}{ operability } & \multirow[b]{3}{*}{$\begin{array}{c}\text { Healing } \\
\text { (days) }\end{array}$} & & & & & \\
\hline & & & & & \multirow[b]{2}{*}{$\begin{array}{l}\text { Hae- } \\
\text { morr- } \\
\text { hage }\end{array}$} & \multirow[b]{2}{*}{$\begin{array}{l}\text { tissue } \\
\text { mobility }\end{array}$} & \multirow[b]{2}{*}{ view } & & \multicolumn{5}{|c|}{ post surgery development /complications } \\
\hline & & & & & & & & & rezidiv & $\begin{array}{l}\text { Defae- } \\
\text { cation }\end{array}$ & \multicolumn{2}{|c|}{$\begin{array}{c}\text { perineal } \\
\text { conformation } \\
b \quad a \\
\end{array}$} & remarks \\
\hline \multirow{6}{*}{ mare } & $1 / 15$ & 14 & 3,5 & circle & 2 & 1 & 1 & 14 & no & +++ & +++ & +++ & - \\
\hline & $2 / 3,5$ & 14 & 11 & $\begin{array}{c}\text { oval } \\
\text { longitudinal }\end{array}$ & 1 & 1 & 1 & 14 & no & +++ & + & +++ & - \\
\hline & $3 / 16$ & 14 & 3,0 & circle & 1 & 2 & 1 & 14 & no & +++ & +++ & +++ & - \\
\hline & $4 / 17$ & 14 & 3,5 & circle & 2 & 2 & 3 & 14 & yes & +++ & +++ & +++ & $\begin{array}{l}\text { recidive } 1,5 \mathrm{~cm} \varnothing \\
2^{\text {nd }} \text { op. } 14 \text { days later } \\
\text { succesfull }\end{array}$ \\
\hline & $5 / 15$ & 14 & 5,0 & circle & 2 & 3 & 4 & 14 & yes & +++ & ++ & +++ & $\begin{array}{l}\text { recidive } 4,0 \mathrm{~cm} \varnothing, \\
2^{\text {nd }} \text { op. } 21 \text { days later } \\
\text { initially succesfull }\end{array}$ \\
\hline & $6 / 18$ & 14 & 7,0 & $\begin{array}{c}\text { oval } \\
\text { transversal }\end{array}$ & 2 & 1 & 1 & 14 & no & +++ & + & +++ & - \\
\hline \multirow{4}{*}{ client } & $7 / 12$ & $\begin{array}{c}6 \\
\text { months }\end{array}$ & 4,0 & $\begin{array}{c}\text { oval } \\
\text { longitudinal } \\
\end{array}$ & 1 & 3 & 2 & 15 & no & ++ & ++ & ++ & $\begin{array}{c}\text { in foal } \\
2^{\text {nd }} \text { following season }\end{array}$ \\
\hline & $8 / 6$ & $\begin{array}{c}6-7 \\
\text { months }\end{array}$ & 2,0 & circle & 2 & 2 & 2 & 16 & no & +++ & ++ & ++ & $?$ \\
\hline & $9 />15$ & $\begin{array}{c}18 \\
\text { months }\end{array}$ & 6,0 & $\begin{array}{c}\text { oval } \\
\text { Innnitudinal } \\
\end{array}$ & 1 & 3 & 2 & 14 & no & ++ & + & +++ & $\begin{array}{c}\text { in foal } \\
\text { following season }\end{array}$ \\
\hline & $10 / 9$ & $?$ & 4,0 & $\begin{array}{c}\text { oval } \\
\text { longitudinal }\end{array}$ & 2 & 2 & 2 & $<17$ & no & +++ & ++ & +++ & $\begin{array}{c}\text { in foal } \\
\text { following season }\end{array}$ \\
\hline & $\begin{array}{c}\bar{X} \\
\min -\max \end{array}$ & $\begin{array}{c}14 \text { days } \\
>18 \\
\text { months }\end{array}$ & $\begin{array}{c}4,9 \\
2-11\end{array}$ & - & - & - & - & $\begin{array}{c}14,3 \\
14-<17\end{array}$ & & & & - & \\
\hline \multicolumn{3}{|c|}{$\begin{array}{l}\text { haemorrhage: } \\
\text { tissue mobility: } \\
\text { view: } \\
\text { defaecation: } \\
\text { perineal conforn }\end{array}$} & $0=$ & \multicolumn{2}{|c|}{$\begin{aligned} 1 & =\text { mild } \\
1 & =\text { easy } \\
1 & =\text { good } \\
+++ & =\text { good } \\
+++ & =\text { good }\end{aligned}$} & \multicolumn{3}{|c|}{$\begin{aligned} 2 & =\text { modest } \\
2 & =\text { fair } \\
2 & =\text { fair } \\
++ & =\text { fair } \\
++ & =\text { fair }\end{aligned}$} & \multicolumn{3}{|c|}{$\begin{array}{l}3=\text { severe } \\
3=\text { difficult } \\
3=\text { sufficient } \\
+=\text { opstipation } \\
+=\text { not sufficient }\end{array}$} & & $\begin{array}{l}4=\text { very difficult } \\
4=\text { limited }\end{array}$ \\
\hline
\end{tabular}

$\mathrm{b} / \mathrm{a}=$ before / after surgery 
mobilisization of the surounding tissue and fixation of the sutures. In 8 out of 10 probands repair of the RVF was successfull in the first attempt. One experimental mare needed a second and onother one needed a third operation. The recidives may be caused by nonsufficiant adaptation of the wound lips during and just after operation. Both mares had strongly developed semitendineus muscles limiting the cleft between the thighs that limited the approach of the the surgery instruments. Other authors (Frank, 1964; Desjardins et al., 1993; LeBlanc, 1998) also gave reports of this situations. In each case RVF recidives were of smaller size than before, making operation procedure somewhat easier than before. There are no precise data about RVF success rates available. The succes rate in this study with a percentage 80 for the first and 90 in the second/resp. third attempt could be qualified as very good so that this modified surgery of RVF repair could be recommended for pratice.

In spite of the fact of a , defect healing' in few wound regions the pathomorphological results demonstrated a complete macroscopic and microscopic healing of the operated RVF which is able to withstand the enormous stress of defaecation peristalsis of the rectum. The question if the operation site is able to withstand the enormous pressure and tensions during second stage of labor remains not sufficiently answered because the experimental mares had been sacrified. Three of the client mares got in foal in the following resp. second following season but there are no information available about the outcoming of these pregnancies. It can be concluded from the results of the postsurgery clinical, ultrasonographical and morphological inves-tigations of the IRF region that a normal delivery of normal sized fetus at term is most likely. As in other foaling mares with a history of a genital surgery measurements to protect the perineo-vestibular complex is strongly recommended.

Finally the modification surgery fulfills the mean aims of the RVF repair (1) durable and stress withstanding closure of the fistula, (2) saving and maintaning the perineal integrity, and (3) offering a reliable perineo-vulvar conformation of the operated mare.

\section{Literature}

Aanes, W. A. (1964): Surgical repair of third-degree perineal laceration and rectovaginal fistula in the mare. J. Am. Vet. Med. Assoc. 144, 485-491

Aanes, W. A. (1974): Progress in recto-vaginal surgery. in: Proceedings of the nineteenth annual convention of the American Association of Equine Practitioners, Atlanta 1973, 225-240

Aanes, W. A. (1988): Surgical management of foaling injuries. Vet. Clin. North Am. Large Anim. Pract. 6, 417-437

Ansari, M. M. and L. E. Matros (1983): Surgical repair of rectovestibular lacerations in mares. Compend. Contin. Educ. Pract. Vet. 5, 129-134

Beard, W. (1991): Standing urogenital surgery. Vet. Clin. North Am.: Equine Pract. 7, 660- 684

Belknap, J. K. and F. A. Nickels (1992): A one-stage repair of thirddegree perineal lacerations and rectovestibular fistulae in 17 mares. Vet. Surg. 21, 378-381

Butterfield, R. M. (1983): The normal vulva \& vagina of the mare. in: Refresher Course for Veterinarians. Proceedings n 65 - Equine Practice-Diagnosis \& Therapy. Sydney Australia

Colbern, G. T., W. A. Aanes and T. S. Stashak (1985): Surgical management of perineal lacerations and rectovestibular fistulae in the mare: A retrospective study of 47 cases. J. Am. Vet. Med. Assoc. 186, 265269
Desjardins, M. R., D. R. Trout and C. B. Little (1993): Surgical repair of rectovaginal fistulae in mares: Twelve cases (1983-1991). Can. Vet. J. 34, 226-231

Dietz, O. and E. Henschel (1988): Anästhesie und Operationen bei Groß- und Kleintieren. 4. Auflag, Ferdinand Enke Verlag, Stuttgart

Dreyfuss, D. J., E. P. Tulleners, W. J. Donawick and N. G. Ducharme (1990): Third-degree perineal lacerations and rectovestibular fistulae in cattle: 20 cases (1981-1988). J. Am. Vet. Med. Assoc. 196, 768-770

Fontijne, P. (1992): Operationstechnik und Ergebnisse bei der Dammrissoperation des Pferdes. Prakt. Tierarzt. 3, 237-240

Frank, E. R. (1964): Tail, anus, rectum, vagina and penis. Veterinary Surgery. 7. Aufl., Burgess, Minneapolis

Götze, R. (1952): Dammrissnaht, Plastik der Vulva und des Scheidenvorhofes bei Stuten und Kühen. 4. Aufl. Verlag Schaper, Hannover

Greenaway, L. (1960): Surgical correction of a recto-vaginal- fistula in a mare. Can. Vet. J. 1, 69-70

Grunert, E. (1993): Geburtsverletzungen und Geburtsschäden des Muttertiers. in: J. Richter und R. Götze (Hrsg.): Tiergeburtshilfe. 4. Aufl., Paul Parey, Berlin, 352-356

Huber, M. J. (1998): Modified technique for single stage rectovestibular fistula closure in three mares. Equine Vet. J. 30, 82-84

Klug, E. (1999): Krankheiten der weiblichen Geschlechtsorgane. in: O. Dietz U. B. Huskamp (Hrsg.): Handbuch Pferdepraxis. 2. Aufl., Ferdinand Enke Verlag, Stuttgart, 578-599

Larsen, L. H. (1983): The repair of recto-vaginal fistula \& cloaca in the mare. in: Refresher Course for Veterinarians. Proceedings $n^{\circ} 65-$ Equine Practice-Diagnosis \& Therapy. Sydney Australia

LeBlanc, M. M. (1998): Third-degree rectovestibular lacerations and fistulas. in: N. A. White and J. N. Moore (Hrsg.): Current Techniques in Equine Surgery and Lameness. 2. Aufl., W.B. Saunders Company, Philadelphia

Mair, T., S. Love, J. Schumacher and E. Watson (1998): Equine medicine, surgery and reproduction. Saunders, London

Merkt, H. and J. C. Merkt (1986): Plastische Operation von Vulva und Scheidenvorhof bei der Stute. Pferdeheilkd. 2, 55-60

Nickels, F. A. (1979): Complications of urogenital surgery. in: Proocedings of the $24^{\text {th }}$ Annual Convention of the American Association of Equine Practitioners 1978. 261-265

Nudelmann, N. (1989): Chirurgie réparatrice d'une fistule recto-vestibulaire chez une jument. Recl. Méd. vét. 165, 35-38

Papa, F. O., M. A. Alvarenga, S. D. Bicudo, C. Meira and N. C. Prestes (1992): Modificaçoes na técnica de correçao cirurgica de dilaceraçao perineal de $3^{\circ}$ grau em éguas. Braz. J. vet. Res. anim. Sci. 29, 239-50

Rossdale, P. D. and S. W. Ricketts (1983): Equine stud farm medicine 2. Aufl., Baillière Tindall, London

Schulz, J., K. Eulenberger and J. Wilhelm (1984): Zum chirurgischen Verschluss von Dammrissen und Scheiden-Mastdarm-Fisteln bei der Stute. Monatsh. Veterinärmed. 39, 816-817

Shokry, M., I. M. Ibraim, A. S. Ahmed and M. A. Abdel Hamid (1986): Preferred suture material in repair of rectovestibular lacerations in mares. Mod. Vet. Pract. 67, 546

Slone, D. E. (1993): Urogenital surgery in the mare. Equine- Pract. 15, $17-21$

Slusher, S. H. (1987): Broodmare infertility - Part 6 - Rectovestibular laceration repair. Mod. Vet. Pract. 68, 532-537

Vaughan, J. T. (1984): Equine urogenital system. in: P. B. Jennings (Hrsg.): The Practice of Large Animal Surgery. Vol. II. Verlag W. B. Saunders Co., Philadelphia, 1127-1132

Walker, D. F. and J. T. Vaughan (1980): Bovine and equine urogenital surgery. Lea \& Febiger, Philadelphia

Wollrab, J. (1984): Bedeutung und Behandlung des mangelhaften Schamschlusses bei der Stute. Monatsh. Veterinärmed. 39, 416-420

\section{Prof. Dr. E. Klug}

Klinik für Pferde

Tierärztliche Hochschule Hannover

Bischofsholer Damm 15

Haus Nr. 178

30173 Hannover

Tel.: (051 1) 8567589

Fax: $(0517) 8567681$ 